\title{
Potensi Antibakteri Ekstrak Etanol dan Etil Asetat Daun Benalu Dendrophtoe pentandra terhadap Klebsiella pneumoniae Penghasil ESBL
}

\author{
Antibacterial Potency of Dendrophtoe petandra Ethanol and Ethyl Asetat Leaves Extract against ESBL \\ Producting Klebsiella pneumoniae
}

Ardy Prian Nirwana*dan Indah Tri Susilowati

Sekolah Tinggi Ilmu Kesehatan Nasional Surakarta

*Corresponding author: ardypriannirwana@gmail.com

\begin{abstract}
ABSTRAK
Antibiotik yang diberikan berlebihan, tidak adekuat dan monoton, dapat mengurangi efektifitas antibiotik, sehingga menimbulkan resistensi terutama pada bakteri. Resitensi Klebsiela sp terhadap antibiotik disebabkan salah satunya karena mampu menghasilkan enzim extended spectrum $\beta$-lactamase (ESBL). ESBL merupakan enzim yang dapat menghidrolisis penicillin, cephalosporin generasi I, II, III dan aztreonam. Dendropthoe pentandra mengandung senyawa metabolit sekunder yang bersifat bakterisida. Penelitian ini bertujuan mengetahui potensi antibakteri ekstrak etanol dan etil asetat daun D.pentandra terhadap K.pneumoniae penghasil ESBL.

Daun D. pentandra diekstraksi menggunakan metode maserasi dengan pelarut etanol $96 \%$ dan etil asetat. Kandungan antibakteri diidentifikasi secara kualitatif dengan uji skrining fitokimia. Desain penelitian adalah deskriptif eksperimental dengan mengukur zona hambat radikal. Uji pendahuluan dan daya hambat bakteri dilakukan dengan metode difusi cakram dikomparasikan dengan kontrol antibiotik cefotaxim, ceftazidim, ceftriaxone dan ciprofloxacin.

Hasil skrining fitokimia menunjukkan bahwa ekstrak etanol dan etil asetat D.pentandra, keduanya mengandung senyawa antibakteri seperti flavonoid, alkaloid, terpenoid, tanin, dan saponin. Konsentrasi hambat tumbuh minimum untuk ekstrak etanol dan etil asetat adalah 50\% dengan rata-rata diameter zona hambat radikal secara berturut-turut adalah 7,25 mm dan 7,38 mm. Uji sensibilitas menunjukkan bahwa bakteri resisten terhadap antibiotik cefotaxim, ceftazidim, dan ceftriaxone tetapi sensitif terhadap ciprofloxacin. Ekstrak etanol dan etil asetat D.pentandra pada konsentrasi $100 \%$ memiliki potensi antibakteri terhadap K.pneumonia lebih baik dibanding kontrol antibiotik beta-laktam dengan zona penghambatan radikal secara berturut-turut adalah 13,55 mm dan 15,38 mm.
\end{abstract}

Kata kunci: ekstrak etanol, ekstrak etil asetat, daun benalu Dendrophtoe pentandra, K.pneumoniae, ESBL

\begin{abstract}
Antibiotics were given excessive, inadequate and monotonous, can reduce the effectiveness of antibiotics, causing resistance, especially in bacteria. Klebsiela sp antibiotic-resistant infections caused one of them for being able to produce the enzyme extended spectrum $\beta$-lactamase (ESBL). ESBL is an enzyme that can hydrolyze penicillin, cephalosporin generation I, II, III and aztreonam. Dendropthoe pentandra contain secondary metabolites that are bactericidal. This study aims to determine the antibacterial potency of ethanol and ethyl acetate extracts of the leaves D.pentandra against ESBL-producing K.pneumoniae.

D. pentandra leaf mistletoe a extracted using maceration method with $96 \%$ ethanol and ethyl acetate. The content of antibacterial identified qualitatively phytochemical screening test. The study design was descriptive experimentally by measuring the inhibition zone radical. Preliminary test and the inhibition of bacteria carried by disc diffusion method dikomparasikan control antibiotic cefotaxime, ceftazidim, ceftriaxone and ciprofloxacin.

Phytochemical screening results showed that ethanol and ethyl acetate extracts D.pentandra, both containing antibacterial compounds such as flavonoids, alkaloids, terpenoids, tannins and saponins. The minimum growth inhibitory concentration for ethanol and ethyl acetate extract is $50 \%$ with an average diameter of inhibitory zone radical respectively are $7.25 \mathrm{~mm}$ and $7.38 \mathrm{~mm}$. Sensibility test showed that bacteria resistant to the antibiotic cefotaxime, ceftazidim, and ceftriaxone but sensitive to ciprofloxacin. The ethanol extract and ethyl acetate D.pentandra at 100\% concentration has antibacterial activity against K. pneumoniae better than control beta-lactam antibiotics with a zone of inhibition of radical respectively is $13.55 \mathrm{~mm}$ and $15.38 \mathrm{~mm}$.
\end{abstract}

Keywords: ethanol extract, ethyl acetate extract, Dendrophthoe pentandra leaves, K.pneumoniae, ESBL 


\section{PENDAHULUAN}

Antibiotik dikonsumsi secara berlebihan, tidak memadai, monoton dapat menimbulkan resistensi terutama pada bakteri gram negatif. Bakteri gram negatif yang paling sering diisolasi di ICU anak di antaranya adalah Escherichia coli dan Klebsiella pneumoniae. Sumber bakteremia tersering adalah infeksi saluran kemih dan pneumonia. Klebsiela sp merupakan salah satu bakteri dari famili Enterobacteriaceae penghasil enzim extended spectrum $\beta$-lactamase (ESBL) yang resisten terhadap cefotaxime di Jerman pada tahun 1983 (Adisasmito, 2004).

ESBL berasal dari mutasi $\beta$-laktamase yang menyebabkan peningkatan aktivitas enzimatik $\beta$-lactamase sehingga enzim ini dapat menghidrolisis chepalosporin generasi III dan aztreonam (Pajirau, 2010). Resistensi mikroba yang meluas terhadap obat-obatan mendorong pentingnya penggalian sumber antimikroba dari bahan alam. Tanaman obat diketahui potensial dikembangkan lebih lanjut pada penyakit infeksi namun masih banyak yang belum dibuktikan aktivitasnya secara ilmiah (Agustiningsih, 2010). Salah satu sumber alam yang dapat dimanfaatkan sebagai obat adalah tanaman benalu Dendropthoe pentandra.

Dendrophtoe pentandra merupakan jenis benalu yang masuk dalam suku Loranthaceae yang dapat memarasit berbagai jenis tumbuhan inang, semak maupun pohon (Sunaryo, 2008). Daun D.pentandra memiliki khasiat antibakteri, hal ini dibuktikan pada penelitian Anita et. al., (2014), dimana ekstrak metanol daun $D$. pentandra mengandung senyawa yang bersifat bakterisida terhadap bakteri di antaranya adalah flavonoid, alkaloid, steroid, polifenol, dan kuinon.

Penelitian ini bertujuan untuk mengetahui potensi antibakteri ekstrak etanol dan etil asetat daun D.pentandra terhadap pertumbuhan K.pneumonia dikomparasikan dengan antibiotik kontrol uji pembentukan ESBL pada bakteri sesuai standar CLSI (Clinical and Laboratory Standars Institute) (2011), serta antibiotik kon- trol positif yang digunakan adalah ciprofloxacin.

\section{BAHAN DAN METODE}

\section{Alat dan bahan}

Daun benalu Dendrophtoe pentandra, inkubator, ohse, pembakar spirtus, object glass, mikroskop, neraca, gelas ukur, pipet ukur, saringan, batang pengaduk, clinic pipet, paper disc, ciprofloxacin, ceftriaxon, ceftaszidime, cefotaxime, DMSO, sampel bakteri K.pneumoniae penghasil ESBL, Mac Conkey, media uji biokimia, kovac,

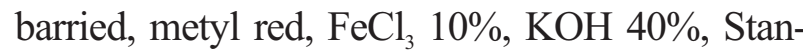
dard Mc farland no. 0,5, Nutrient agar, aquades, Nutrient broth, Nutrient agar plate, $\mathrm{NaCl}$ 0,9\% steril, $\mathrm{HCl} 2 \mathrm{M}, \mathrm{NaCl}$, reagen Wagner, reagen Dogendarf, reagen Meyer $\mathrm{HCl}$ pekat, etanol 96\%, etil asetat.

\section{Cara Kerja \\ Persiapan Sampel}

Sampel daun D.pentandra dikeringkan di bawah sinar matahari secara tidak langsung dengan cara ditutup dangan kain hitam selama 6 hari, kemudian dilanjutkan di dalam inkubator dengan suhu $50^{\circ} \mathrm{C}$ (Andriyani et. al., 2010).

\section{Ekstraksi}

Daun D.pentandra kering digiling hingga halus dan diayak, selanjutnya ditimbang. Sebanyak masing-masing 100 gram sampel yang telah dihaluskan, dimaserasi dalam $750 \mathrm{ml}$ etanol 96\% dan etil asetat selama 5 hari sambil diaduk-aduk. Dilakukan penyaringan dengan kertas saring. Ekstrak yang diperoleh dilakukan pengeringan dengan Rotavapour hingga kental. Hasil ekstrak berwarna kental hitam kehijauan.

\section{Analisis skrining fitokimia}

1) Skrining flavonoid dilakukan dengan cara ditambahkan serbuk Mg dan 2 ml HCl 2N pada 2 mL larutan ektrak. Senyawa flavonoid akan menunjukkan warna jingga sampai merah.

2) Skrining alkaloid dilakukan dengan cara $3 \mathrm{ml}$ larutan ekstrak ditambahkan dengan $1 \mathrm{ml} \mathrm{HCl} 2 \mathrm{~N}$ 
dan $6 \mathrm{ml}$ air suling, kemudian dipanaskan selama 2 menit, didinginkan dan disaring. Filtrat diperiksa dengan pereaksi Mayer terbentuk endapan putih.

3) Skrining saponin dilakukan dengan sampel ditambahkan aquades. Kemudian dikocok vertikal selama 10 detik. Hasil uji positif jika timbul busa stabil selama 10 menit (Harborne, 1987 dalam Sukandar et. al., 2008).

4) Skrining tanin dilakukan dengan cara sebanyak $1 \mathrm{~mL}$ larutan ekstrak uji direaksikan dengan $\mathrm{FeCl} 3$ 10\%, adanya tanin ditunjukkan dengan terbentuknya warna biru tua atau hitam kehijauan.

5) Skrining terpenoid dilakukan dengan cara bahan uji dilarutkan dengan kloroform, kemudian ditambahkan dengan asam asetat anhidrat sebanyak $0,5 \mathrm{ml}$, selanjutnya ditambahkan $2 \mathrm{ml}$ asam sulfat pekat melalui dinding tabung. Adanya triterpenoid ditandai dengan terbentuknya cincin kecoklatan atau violet pada perbatasan larutan, sedangkan adanya steroid ditandai dengan terbentuknya cincin biru kehijauan (Padmasari et. al., 2013).

\section{Uji Daya Hambat Difusi Cakram}

\section{Pembuatan Standar Kekeruhan Larutan}

Larutan asam sulfat $0,36 \mathrm{~N}$ sebanyak 99,5 ml dicampurkan dengan larutan $\mathrm{BaCl}_{2} \cdot 2 \mathrm{H}_{2} \mathrm{O}$ $1,175 \%$ sebanyak $0,5 \mathrm{~mL}$ dalam erlenmeyer kemudian dikocok sampai terbentuk larutan yang keruh. Kekeruhan ini dipakai sebagai standar kekeruhan suspensi bakteri uji. Pembuatan suspensi bakteri uji bakteri uji pada media agar miring diambil dengan kawat ose steril lalu disuspensikan ke tabung yang berisi $2 \mathrm{~mL}$ larutan $\mathrm{NaCl}$ 0,9 \% hingga diperoleh kekeruhan yang sama dengan standar kekeruhan larutan Mc. Farland (Ngajowa et. al., 2013).

\section{Uji antibakteri ekstrak D.pentandra}

Uji aktivitas antibakteri ekstrak benalu menggunakan metode difusi disk yang telah dimodifikasi. Suspensi bakteri K.pneumonie $\left(10^{8} \mathrm{CFU} / \mathrm{mL}\right)$ disebar merata pada media Nutrient Agar dengan teknik swab, selanjutnya, kertas cakram ditetesi dengan variasi konsentrasi masing-masing ekstrak D.pentandra, kontrol negatif (aquades steril), dan untuk mengkonfirmasi resistensi sampel bakteri terhadap antibiotik, digunakan kontrol antibiotik beta-laktam dari golongan Cephalosporin (Ceftriaxon, cefotaxime, dan ceftazidime) control positif dengan antibiotic ciprofloxacin. Cawan petri kemudian diinkubasi pada suhu $37^{\circ} \mathrm{C}$ selama 24 jam. Amati adanya diameter zona hambat radikal yaitu daerah jernih tanpa pertumbuhan bakteri (CLSI, 2011; Pajirau, 2010; Widyaningtyas et. al., 2014).

\section{Hasil}

\section{Analisis Skrining Fitokimia}

Skrining fitokimia dilakukan untuk mengetahui metabolit sekunder dalam ekstrak D.pentandra yang bersifat antibakteri (Tabel 1).

Berdasarkan Tabel 1. Baik ektrak etanol dan etil asetat mengandung flavonoid, alkaloid, tannin, terpenoid dan saponin.

\section{Uji sensibilitas kontrol antibiotik}

Tabel 2. Menunjukkan bahwa sampel bakteri K. pneumonie resisten terhadap kontrol antibiotik beta-laktam dan sensitif terhadap ciprofloxacin

\section{Uji antibakteri ekstrak D.pentandra}

Hasil uji pendahuluan menunjukkan bahwa konsentrasi hambat tumbuh minimum untuk

\begin{tabular}{|c|c|c|c|}
\hline \multirow[t]{2}{*}{ No } & \multirow[t]{2}{*}{ Uji } & \multicolumn{2}{|c|}{ Hasil } \\
\hline & & Etanol & Etil Asetat \\
\hline 1 & Flavonoid & (+) Jingga & (+) Jingga \\
\hline 2 & Alkaloid & $(+)$ Endapan putih & (+) Endapan putih \\
\hline 3 & Tanin & $\begin{array}{l}(+) \text { Endapan coklat } \\
\text { kehijauan }\end{array}$ & $\begin{array}{c}(+) \text { Endapan } \\
\text { coklat kehijauan }\end{array}$ \\
\hline $\begin{array}{l}4 \\
5\end{array}$ & $\begin{array}{l}\text { Terpenoid } \\
\text { Saponin }\end{array}$ & $\begin{array}{c}(+) \text { Cincin coklat } \\
(+) \text { Busa }\end{array}$ & $\begin{array}{l}(+) \text { Cincin coklat } \\
(+) \text { Busa }\end{array}$ \\
\hline
\end{tabular}


Tabel 2. Hasil Uji Sensibilitas

\begin{tabular}{lcccc}
\hline Antibiotik & \multicolumn{2}{c}{$\begin{array}{c}\text { Interpretasi Sensibilitas } \\
\text { (CLSI, 2011) }\end{array}$} & $\begin{array}{c}\text { Rata-rata } \\
\text { diameter zona } \\
\text { hambat (mm) }\end{array}$ \\
& Sensitif & Intermediet & Resisten & \\
\hline Ciprofloxcacin & $\geq 21$ & $16-20$ & $\leq 15$ & 26,125 \\
Cefotaxime & $\geq 26$ & $23-25$ & $\leq 22$ & 6 \\
Ceftazidime & $\geq 21$ & $18-20$ & $\leq 17$ & 13,25 \\
Ceftriaxone & $\geq 23$ & $20-22$ & $\leq 19$ & 6 \\
\hline
\end{tabular}

Tabel 3. Pendahuluan Antibakteri

\begin{tabular}{ccc}
\hline Konsentrasi & \multicolumn{2}{c}{ Rata-rata zona hambat radikal (mm) } \\
\cline { 2 - 3 } & Etil Asetat & Etanol \\
\cline { 2 - 3 } $\mathbf{1 0 0 \%}$ & 10,875 & 11,75 \\
$\mathbf{5 0 \%}$ & 7,375 & 7,25 \\
$\mathbf{2 5 \%}$ & 6 & 6 \\
$\mathbf{1 2 , 5 \%}$ & 6 & 6 \\
$\mathbf{6 , 2 5 \%}$ & 6 & 6 \\
$\mathbf{3 , 1 2 5 \%}$ & 6 & 6 \\
$\mathbf{1 , 6 5 2 5} \%$ & 6 & 6 \\
\hline
\end{tabular}

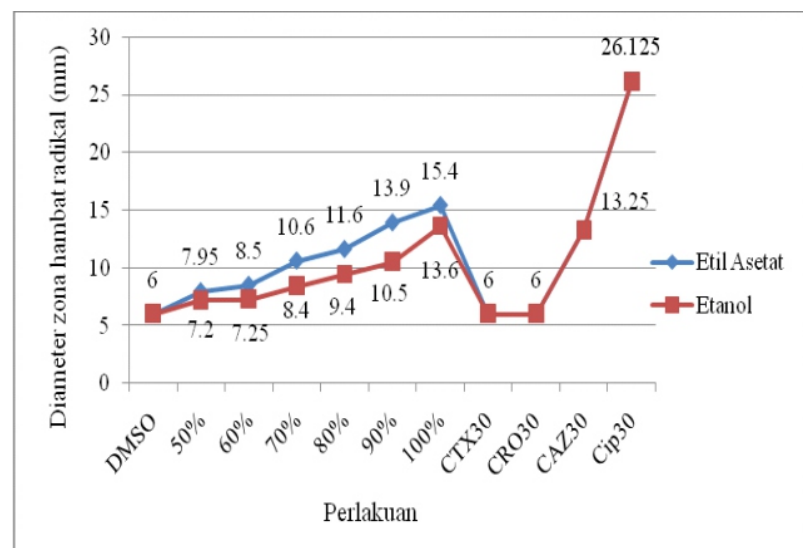

Gambar 1. Hasil Uji Difusi Cakram

ekstrak etanol dan etil asetat sama yaitu pada konsentrasi ekstrak 50\%, konsentrasi ini dijadikan patokan untuk uji selanjutnya (Tabel 3).

\section{PEMBAHASAN}

Klebsiella pneumoniae merupakan bakteri Gram negatif dan dikategorikan ke dalam anaerob fakultatif, bakteri ini termasuk dalam famili Enterobacteriaceae (Jawetz et al., 2008). Bakteri golongan Enterobacteriaceae banyak ditemukan mengalami resistensi terhadap antibiotik golongan beta-laktam, hal ini terjadi salah satunya disebabkan oleh penggunaan antibiotik yang tidak bijak (Pajirau, 2010; Sari, 2015). Resistensi bakteri terhadap antibiotik golongan beta-laktam terjadi karena bakteri mampu menghasilkan ESBL yang merupakan enzim plasmid yang memerantarai terjadinya hidrolisis dan inaktivasi dari antibiotika beta-laktam termasuk sefalosforin generasi ketiga, penisilin dan aztreonam (Irawan, 2012). Pengujian skrining dan konfirmatif untuk mengetahui kemampuan K.pneumoniae dalam menghasilkan ESBL dapat dilakukan dengan uji sensibilitas menggunakan beberapa antibiotik, di antaranya adalah Ceftazidime, Cefotaxime, dan Ceftriaxone (CLSI, 2011).

Hasil uji antibakteri metode difusi cakram (Gambar 1) menunjukkan bahwa ekstrak etanol dan etil asetat D.pentandra pada konsentrasi 100\% memiliki potensi antibakteri yang lebih baik dalam menghambat pertumbuhan K.pneumoniae dibandingkan dengan kontrol antibiotik ESBL (cefotaxime, ceftazidime, dan ceftriaxone). Potensi penghambatan ini dikarenakan kandungan antibakteri dalam kedua ekstrak tersebut antara lain; flavonoid, alkaloid, terpenoid, tanin dan saponin.

Flavonoid memiliki aktivitas sebagai anti- 
bakteri karena dapat mendenaturasi protein sel dan merusak membran sel bakteri. Mekanisme flavonoid sebagai antibakteri berhubungan dengan pembentukan ikatan kompleks dengan protein pada membran (protein-fenol) sehingga menyebabkan permiabilitasnya turun. Ikatan kompleks yang telah terbentuk kemudian terurai dan berpenetrasi ke dalam sel sehingga terjadi koagulasi protein dan menyebabkan enzim bakteri tidak aktif. Akibatnya dinding sel bakteri tidak terbentuk dengan baik sehingga terjadi kebocoran sel dan bakteri mati (Zabadi, 2011). Alkaloid sebagai agen antibakteri bekerja dengan cara menghambat sintesis dinding sel bakteri dan mengganggu komponen penyusun peptidoglikan, sehingga lapisan dinding sel tidak terbentuk secara utuh dan menyebabkan kematian sel tersebut. Mekanisme antibakteri steroid yaitu dengan menghambat sintesis dinding sel bakteri dengan cara menghasilkan membran sehingga menyebabkan kebocoran pada liposom yang merupakan penyusun dinding sel bakteri (Ambarsari, 2013). Tanin diduga dapat mengkerutkan dinding sel. Rusaknya dinding sel akan menyebabkan terhambatnya perumbuhan sel bakteri, dan pada akhirnya bakteri akan mati. Secara umum adanya kerja suatu bahan kimia sebagai zat antibakteri dapat mengakibatkan terjadinya perubahan-perubahan yang mengarah pada kerusakan hingga terhambatnya pertumbuhan sel bakteri tersebut (Retnowati et. al., 2011).

Walaupun demikian tidak ada di antara variasi konsentrasi ekstrak etanol dan etil asetat yang memiliki potensi penghambatan menyamai antibiotik ciprofloxacin, hal ini bisa terjadi kemungkinan karena antibiotik merupakan dosis tunggal yang kemampuan bakteriosidalnya telah teruji. Rieuwpassa dan Hatta (2009) menjelaskan bahwa ciprofloxacin merupakan agen generasi kedua, salah satu obat sintetik derivat quinolon. Mekanisme kerjanya adalah menghambat aktivitas DNA gyrase bakteri, bersifat bakterisidal dengan spektrum luas terhadap bakteri Gram-positif maupun negatif.
Berdasarkan Gambar 1. ekstrak etil asetat D. pentandra yang memiliki potensi antibakteri lebih dibanding ekstrak etanol 96\%. Septiana dan Asnani (2012) menjelaskan bahwa hasil total etanol dalam suatu bahan dengan metode ekstraksi baik menggunakan 1 maupun 2 tahap, didapatkan total fenol (flavonoid, tannin) paling tinggi pada pelarut etil asetat diikuti oleh etanol dan yang paling rendah adalah aquades, kemungkinan hal inilah yang menyebabkan potensi antibakteri ekstrak etil asetat yang lebih baik.

\section{KESIMPULAN}

Dari penelitian yang telah dilakukan dapat disimpulkan bahwa ekstrak etanol dan etil asetat pada konsentrasi D.pentandra memiliki potensi antibakteri dalam menghambat pertumbuhan K.pneumoniae penghasil ESBL lebih baik daripada antibiotik cefotaxime, ceftazidime.

\section{DAFTAR PUSTAKA}

Agustiningsih, E.T. 2010. Aktivitas Antibakteri Ekstrak Etanol Daun Benalu Jambu Air (Dendrophthoe falcata (L.f.) Ettingsh) Terhadap Escherichia coli Dan Staphylococcus aureus. Skripsi. Fakultas Farmasi Universitas Muhammadiyah Surakarta

Ambarsari, M.A. 2013. Aktivitas Antibakteri Fraksi N-Heksan Ekstrak Etanol Daging Buah Sirsak (Annona muricata L.) Terhadap Pseudomonas aeruginosa, Staphylococcus aureus, Shigella sonnei dan Serta Bioautografinya. Skripsi. Universitas Muhammadiyah Surakarta

Andriyani, D., Utami, P I., Dhiani, B A. 2010. Penetapan Kadar Tanin Daun Rambutan (Nephelium lappaceum.L ) Secara SpektrofotometrI Ultraviolet Visibel. Pharmacy 07 (02): 1-11.

Anita, A.,Siti, K \& Yanti, A.H. 2014. Aktivitas Antibakteri Ekstrak Daun Benalu Jambu Air (Dendropthoe pentandra (L.) Miq) Terhadap Pertumbuhan Salmonella typhi. Probiont 3 (2): $268-272$

CLSI (Clinical and Laboratory Standarts Institute). 2011. Performance Standards for Antimicrobial Susceptibility Testing; Twenty-First Informational Supplement. Replaces M100S20 and M100-S20-U. Vol. 31 No. 1

Irawan, D., Hamidah., Purwati., Triyono, E.A., \& Bramantono. 2012. Profil Penderita Sepsis Akibat Bakteri Penghasil ESBL. Jurnal Penyakit Dalam 13 (1): 63-68

Jawetz, Melnick, dan Adelberg. 2008. Mikrobiologi Kedokteran Edisi 23. Jakarta: Penerbit Buku Kedokteran EGC

Ngajowa, M., Abidjulua, J \& Kamua, V.S. 2013. Pengaruh Antibakteri Ekstrak Kulit Batang Matoa (Pometia pinnata) terhadap Bakteri Staphylococcus aureus secara In vitro. Jurnal MIPA Unsrat Online 2 (2): 128-132

Padmasari, P D., Astuti, K W., Warditiani, N K. 2013. Skrining Fitokimia Ekstrak Etanol 70\% Rimpang Bangle (Zingiber purpureum Roxb.). Jurnal Farmasi Udayana 2 (4): 1-4

Pajirau, A. 2010. Infeksi Oleh Bakteri Penghasil Extended-Spectrum Beta-Lactamase (ESBL) Di RSUP Dr. Kariadi Sema- 
rang: Faktor Risiko Terkait Penggunaan Antibiotik. Artikel Ilmiah. Program Pendidikan Sarjana Kedokteran Fakultas Kedokteran Universitas Diponegoro Semarang

Retnowati, Y., Bialangi, N \& Posangi, N.W. 2011. Pertumbuhan Bakteri Staphylococcus aureus Pada Media Yang Diekspos Dengan Infus Daun Sambiloto (Andrographis paniculata). Saintek Vol 6, No 2

Rieuwpassa, I E dan Hatta, M. 2009. Deteksi Mutasi Gen Gyrase A Porphyromonas gingivalis Resisten terhadap Ciprofloxacin berdasarkan teknik Polymerase Chain Reaction. Jurnal Kedokteran Yarsi 17 (1) : 011-020

Sari, M. 2015. Uji Bakteriologis dan Resitensi Antibiotik Terhadap Bakteri Escherichia coli dan Shigella sp Pada Makanan Gado-gado di Kantin UIN Syarif Hidayatullah Jakarta. Skripsi. Fakultas Kedokteran dan Ilmu Kesehatan Universitas Islam Negeri Syarif Hidayatullah Jakarta

Septiana, A T dan Asnani, A. 2012. Kajian Sifat Fisiokimia Ekstrak Rumput Laut Coklat Sargassum duplicatum menggunakan berbagai pelarut dan Metode Ekstraksi. Agrointek
6 (1): $22-28$

Sukandar, D., Hermanto, S., \& Lestari, E. 2008. Uji Toksisitas Ekstrak Daun Pandan Wangi (Pandanus amaryllifolius Roxb.) Dengan Metode Brine Shrimp Lethality Test (BSLT). Jurnal Valensi 1 (2): 63-70

Sunaryo. 2008. Pemarasitan Benalu Dendrophthoe pentandra (L.) Miq. pada Tumbuhan Koleksi Kebun Raya Cibodas, Jawa Barat. Bidang Botani, Puslit Biologi - LIP. Jurnal Natur Indonesia 11(1): 48-58

Widyaningtias, N. M. S. R., Yustiantara, P. S., \& Paramita, N. L. P.V. 2014. Uji Aktivitas Antibakteri Ekstrak Terpurifikasi Daun sirih hijau (Piper betle L.) Terhadap Bakteri Propionibacterium acnes. Jurnal Farmasi Udayana 3 (1): 50-53

Zabadi, F. 2011. Daya Hambat Fraksi Semipolar Ekstrak Etanol Daun Benalu Mangga (Dendrophthoe petandra (L.) Miq.) Terhadap Pertumbuhan Escherichia coli Serta Brine Shrimp Lethality Test. Skripsi. Fakultas Farmasi Universitas Muhammadiyah Surakarta 